УДК $342.742(477)$

DOI https://doi.org/10.32837/pyuv.v1i3(28).322

\author{
Б. М. Шамрай \\ кандидат юридичних наук, \\ помічник начальника \\ Головного управління з правової роботи \\ Головного управління морально-психологічного забезпечення \\ Збройних сил України
}

\title{
ПРАВОВІ АСПЕКТИ ОБМЕЖЕННЯ КОНСТИТУЦЙНИХ ПРАВ ТА СВОБОД ВІЙСЬКОВОСЛУЖБОВЦІВ ПІД ЧАС ДІЇ ПРАВОВОГО РЕЖИМУ ВОЄННОГО СТАНУ
}

В умовах правового режиму воєнного стану на період його дії можуть обмежуватись окремі конституційні права та свободи людини і громадянина. Зокрема, у зв'язку з уведенням в Україні воєнного стану відповідно до Указу Президента України «Про введення воєнного стану в Україні» від 26 листопада 2018 р. № 393 тимчасово, на період дії правового режиму воєнного стану, обмежувалися конституційні права і свободи, передбачені ст. ст. 30-34, 38, 39, 41-44, 53 Конституції України [1]. Водночас на військовослужбовців під час дії зазначеного правового режиму, поширюються обмеження прав та свобод, передбачені військовим законодавством.

Питання обмежень прав і свобод військовослужбовців Збройних сил України й інших військових формувань в умовах воєнного стану набуває надзвичайно великого значення і безпосередньо впливає на результати сучасної військової реформи. Тому для ефективної реалізації конституційних прав та свобод військовослужбовців необхідно розглянути правові аспекти обмеження конституційних прав і свобод військовослужбовців під час дії правового режиму воєнного стану.

Наукова проблематика щодо прав та свобод військовослужбовців Збройних сил України й інших військових формувань, утворених відповідно до законодавства, активно досліджується вітчизняними вченими-правниками. Питанням прав, свобод і обов'язків військовослужбовців під час проходження ними військової служби присвячені наукові дослідження таких учених, як: Ю.О. Бобров, В.В. Богуцький, Є.I. Григоренко, Я.О. Григоренко, В.В. Забарський, I.I. Качан, М.В. Кушнір, Л.П. Медвідь, С.П. Пасіка, В.Й. Пашинський, А.М. Синиця й інших. Водночас питання обмежень конституційних прав та свобод військовослужбовців під час дії правового режиму воєнного стану залишається недостатньо дослідженим.

Мета статті полягає у висвітленні правових аспектів обмеження конституційних прав та свобод військовослужбовців під час дії правового режиму воєнного стану, зокрема в аналізі нормативно-правових актів, які регулюють зазначене питання.

Конституцією України передбачено, що в умовах воєнного або надзвичайного стану можуть встановлюватися окремі обмеження прав і свобод із зазначенням строку дії цих обмежень (ст. 64) [2]. Зазначені обмеження прав та свобод стосуються також осіб, які проходять військову службу у Збройних силах України й інших військових формуваннях. Крім того, під час дії правового режиму воєнного стану на військовослужбовців поширюються окремі обмеження прав і свобод, які передбачені військовим законодавством, зокрема нормативно-правовими актами, що регулюють проходження військової служби та стосуються соціального захисту військовослужбовців.

Перш ніж розглянути законодавчі й інші нормативно-правові акти, які регулюють питання обмеження конституційних прав та свобод військовослужбовців в умовах воєнного стану, необхідно зупинитися на терміні «обмеження». Обмеження прав громадян визначають як закріплені в нормативно-правових актах юридичні заходи, що вводяться для досягнення суворо визначених цілей, спрямовані на встановлення перешкод для реалізації громадянами тих чи інших прав і забезпечують дотримання необхідного балансу інтересів особи, суспільства і держави [3, с. 46]. Щодо обмежень прав та свобод військовослужбовців, то вони пов'язані з належним виконанням службових обов'язків, підтриманням належного рівня бойової та мобілізаційної готовності військ і $\mathrm{\epsilon}$ об'єктивно необхідними, ураховуючи специфіку військової служби [4, с. 84].

Отже, варто погодитися з думкою, що військовослужбовці є громадянами України, які виконують почесний обов'язок із захисту Батьківщини. Виконання цього обов'язку пов'язано з певними обмеженнями [5, с. 30]. Також слушною є думка, що, реалізуючи військовий обов'язок, громадянин починає проходити військову службу, та його статус трансформується у статус військовослужбовця, що пов'язано з обмеженням деяких конституційних прав і свобод [6, с. 146-147]. Тобто на військовослужбовців поширюються окремі обмеження прав та свобод, які пов'язані з виконанням ними обов'язків військової служби. Тому слушною є позиція, що виконання громадянином обов'язків військової служби зумовлює те, що стосовно його прав і свобод діятимуть деякі обме- 
ження, що передбачені законодавчо і випливають з особливостей військової служби [7, с. 33]. Проте така особливість правового статусу військовослужбовців, як обмеження їх у певних правах, пояснюється інтересами суспільства та необхідністю усунення армії від політичної ролі в державі, необхідністю охорони спеціальних інтересів армії, а також забезпечення в ній дисципліни та військового порядку [8, с. 261].

Варто зазначити, що в умовах дії правового режиму воєнного стану можуть встановлюватися окремі обмеження прав і свобод військовослужбовців, які передбачені в низці законодавчих та інших нормативно-правових актах. Зокрема, законами України «Про військовий обов’язок і військову службу» [9], «Про соціальний і правовий захист військовослужбовців та членів їх сімей» [10], Положенням про проходження громадянами України військової служби у Збройних силах України, затвердженим Указом Президента України від 10 грудня 2008 р. № 1153/2008 [11], та іншими нормативно-правовими актами.

Відповідно до зазначених нормативно-правових актів, для військовослужбовців в умовах воєнного стану встановлюються деякі обмеження щодо проходження військової служби та строків звільнення їх із військової служби. Так, для військовослужбовців, у яких закінчився строк військової служби, військова служба продовжується понад встановлені строки з моменту введення воєнного стану до оголошення демобілізації. Але це не стосується випадків, коли можуть звільнятися з військової служби:

- військовослужбовиі строкової військової служби: за станом здоров'я; за сімейними обставинами; у зв'язку з набранням чинності обвинувальним вироком суду, яким призначено покарання у виді позбавлення волі;

- військовослужбовиі, які проходять військову службу за призовом осіб офічерського складу: за станом здоров'я; через сімейні обставини або з інших поважних причин; у зв'язку з набранням чинності обвинувальним вироком суду, яким призначено покарання у виді позбавлення волі, обмеження волі або позбавлення військового звання; у зв'язку з позбавленням військового звання в дисциплінарному порядку; у зв'язку з небажанням продовжувати військову службу військовослужбовцем-жінкою, яка має дитину (дітей) віком до 18 років; у зв'язку із припиненням громадянства України;

- військовослужбовиів, які проходять військову службу за контрактол: за віком; за станом здоров'я; у зв'язку з набранням чинності обвинувальним вироком суду, яким призначено покарання у виді позбавлення волі, обмеження волі або позбавлення військового звання (ст. ст. 23, 26) [9].

Отже, в умовах правового режиму воєнного стану військовослужбовцям обмежуються такі ок- ремі права, як конституційне право на державне пенсійне забезпечення у випадках, передбачених Конституцією України та Законом України «Про пенсійне забезпечення осіб, звільнених з військової служби, та деяких інших осіб» [12]. Водночас обчислення вислуги років для них під час дії зазначеного правового режиму залишається незмінним. Тому, на нашу думку, після набуття військовослужбовцями права на пенсію, ураховуючи продовження військової служби в умовах правового режиму воєнного стану, їм доцільно виплачувати пенсійне забезпечення, а також здійснювати обчислення вислуги років на пільгових умовах, як-от один місяць служби за три місяці. Це, у свою чергу, компенсуватиме підвищені навантаження, пов'язані з виконанням обов'язків військової служби та стимулюватиме до подальшого проходження військової служби в лавах Збройних сил та інших військових формуваннях.

Обмеження конституційних прав та свобод військовослужбовців під час дії правового режиму воєнного стану також стосуються надання їм відпусток. Так, в особливий період під час дії воєнного стану військовослужбовцям можуть надаватися тільки відпустки за сімейними обставинами та з інших поважних причин зі збереженням грошового забезпечення тривалістю не більш десяти календарних днів без урахування часу, необхідного для проїзду в межах України до місця проведення відпустки та назад, але не більше двох діб в один кінець (ст. 10-1). В особливий період зазначені відпустки надаються без проїзду до місця проведення відпустки та назад. А в умовах повсякденної діяльності така відпустка надається без збереження грошового забезпечення (ст. 10-1) [10]. Отже, військовослужбовцям в умовах воєнного стану не надаються щорічні основні відпустки, передбачені законодавством, зокрема ст. 45 Конституції України, окрім відпусток за сімейними обставинами та з інших поважних причин. Ураховуючи зазначене, на нашу думку, під час дії правового режиму воєнного стану необхідно передбачити виплати грошових компенсацій за невикористані щорічні основні відпустки в рік набуття права на них.

Окремо слід звернути увагу на те, що відкликання військовослужбовців із щорічних основних відпусток дозволяється: за рішенням Міністра оборони України, керівників центральних органів виконавчої влади й інших державних органів, які, відповідно до закону, здійснюють керівництво військовими формуваннями, утвореними відповідно до законів України, начальника Генерального штабу - Головнокомандувача Збройних сил України, а також командувачів відповідних військових формувань, які за посадою не є керівниками центральних органів виконавчої влади. Проте в разі введення воєнного стану в Україні або в окремих її місцевостях відкликання військовос- 
лужбовців із щорічних основних відпусток здійснюється без рішень вищезгаданих посадових осіб (ст. 10-1) [10] (п. 192-1) [11]. Тобто в разі введення правового режиму воєнного стану відкликати із щорічних основних відпусток військовослужбовців дозволяється посадовим особам, які направили їх у відпустки. Однак у повсякденній діяльності військовослужбовці відкликаються з відпустки, зокрема в Міноборони та Збройних силах України, за рішенням Міністра оборони або начальника Генерального штабу - Головнокомандувача Збройних сил України.

Отже, ураховуючи нормативно-правову базу, якою передбачено окремі обмеження конституційних прав та свобод військовослужбовців, 3 упевненістю варто погодитися з тим, що особливістю конституційно-правового статусу військовослужбовців $є$ те, що через специфіку виконання ними особливого виду державної служби - військової служби - вони користуються конституційними правами і свободами з певними обмеженнями, які передбачені законодавством, і визначаються особливостям проходження військової служби [7, с. 128]. Військова служба, її характер, підвищена небезпека для життя осіб, що їі проходять, додаткові обов'язки, підвищені навантаження, додаткова відповідальність, обмеження конституційних прав і свобод, інші обставини відрізняють їі як від інших видів державної служби, так і взагалі від інших видів діяльності людини, передбачають необхідність додаткових соціальних i правових гарантій для осіб, що її проходять [6, с. 34-35]. Тобто поряд з обмеженнями конституційних прав і свобод в умовах дії правового режиму воєнного стану військовослужбовцям передбачено відповідні гарантії прав і свобод, зокрема це стосується надання відпусток за сімейними обставинами та 3 інших поважних причин зі збереженням грошового забезпечення без урахування часу, необхідного для проїзду в межах України до місця проведення відпустки та назад тощо.

Отже, здійснене в нашій статті наукове дослідження вказує на те, що на військовослужбовців як осіб з особливим правовим статусом, крім загального законодавства, також поширюється військове законодавство, яке передбачає окремі обмеження конституційних прав і свобод військовослужбовців під час дії правового режиму воєнного стану. Зазначені обмеження пов'язані 3 належним виконанням службових обов'язків, підтриманням належного рівня бойової та мобілізаційної готовності військ (сил) та стосуються, зокрема, строків проходження й умов звільнення з військової служби, а також надання військовослужбовцям відпусток та відкликання з них. Це питання потребує подальших досліджень і нормативно-правового вдосконалення шляхом закріплення на законодавчому рівні, зокрема отримання під час проходження військової служби грошової компенсації за невикористані щорічні відпустки та виплати пенсійного забезпечення особам, які за вислугою років військової служби мають право на пенсію.

\section{Jimepamypa}

1. Про введення воєнного стану в Україні : Указ Президента України від 26 листопада 2018 р. № 393. URL: https://zakon.rada.gov.ua/laws/show/393/2018.

2. Конституція України : Закон України від 28 червня 1996 р. № 254к/96-BP. URL: http:/ /zakon2.rada.gov. ua/laws/show $/ 254 \%$ D0\% BA/96- $\%$ D0 $\%$ B $\%$ D $1 \% 80$.

3. Опалева C.A. О критериях и принципах допустимого ограничения прав граждан. Вестник Московского университета Министерства внутренних дел. 2005. № 1. С. 46-49.

4. Медвідь Л.П. Права, свободи та обов'язки військовослужбовців в Україні: конституційно-правові аспекти : дис. ... канд. юрид. наук: 12.00.02. Київ, 2016. 249 c.

5. Пасіка С.П. Адміністративно-правове регулювання соціального забезпечення військовослужбовців Збройних сил України : автореф. дис. ... канд. юрид. наук: 12.00.07. Запоріжжя, 2011. 221 с.

6. Богуцький B.В., Григоренко Є.I., Григоренко Я.О. Право на проходження військової служби у контексті забезпечення воєнної безпеки сучасної держави : монографія. Харків : Право, 2019. 274 с.

7. Пашинський В.Й. Конституційно-правовий статус військовослужбовців в Україні : дис. ... канд. юрид. наук: 12.00.02. Київ, 2007. 205 с.

8. Військове право : підручник / за ред. I.M. Коропатніка, I.М. Шопіної. Київ : Алерта, 2019. 648 с.

9. Про військовий обов'язок і військову службу : Закон України від 28 червня 1996 р. № 254к/96-ВР. URL: http://zakon2.rada.gov.ua/laws/show $/ 254 \%$ D0 $\%$ BA/96- $\%$ D0 $\%$ B $\%$ D $1 \% 80$.

10. Про соціальний i правовий захист військовослужбовців та членів їх сімей : Закон України від 28 червня 1996 р. № 254к/96-BP. URL: http://zakon 2.rada.gov.ua/laws / show / $254 \%$ D0 $\%$ BA $/ 96-\%$ D0 $\%$ B2 $\%$ D1 $\% 80$.

11. Про Положення про проходження громадянами України військової служби у Збройних силах України : Указ Президента України від 10 грудня 2008 p. № $1153 / 2008$. URL: https://zakon.rada.gov.ua/laws/ show $/ 393 / 2018$.

12. Про пенсійне забезпечення осіб, звільнених 3 військової служби, та деяких інших осіб : Закон України від 28 червня 1996 р. № 254к/96-BP. URL: http://zakon2.rada.gov.ua/laws/show/254\% D0\% BA/ 96- $\%$ D0\% B2\% D1\% 80 . 


\section{Анотація}

Шамрай Б. М. Правові аспекти обмеження конституційних прав та свобод військовослужбовців під час дії правового режиму воєнного стану. - Стаття.

У статті розглядаються правові аспекти обмеження конституційних прав та свобод військовослужбовців під час дії правового режиму воєнного стану. Висвітлено погляди вчених щодо розуміння обмежень прав та свобод осіб, які проходять військову службу у Збройних силах України й інших військових формуваннях. Зазначається, що обмеження прав і свобод військовослужбовців об'єктивно необхідні, ураховуючи специфіку військової служби, а також пов'язані 3 належним виконанням службових обов'язків, підтриманням належного рівня бойової та мобілізаційної готовності військ (сил).

Проаналізовано нормативно-правові акти, що визначають основні засади державної політики у сфері соціального захисту військовослужбовців та регулюють проходження військової служби, якими передбачено окремі обмеження конституційних прав і свобод військовослужбовців в умовах правового режиму воєнного стану. 3'ясовано, що особливістю конституційно-правового статусу військовослужбовців є те, що, виконуючи обов'язки військової служби, вони користуються конституційними правами і свободами 3 певними обмеженнями, які передбачені законодавством $і$ визначаються особливостями проходження військової служби. Встановлено, що обмеження прав та свобод військовослужбовців в умовах правового режиму воєнного стану зумовлюються тим, що на військовослужбовців, крім загального законодавства, також поширюється військове законодавство, яке обмежує окремі іхні конституційні права, зокрема конституційне право на пенсійне забезпечення та надання щорічних відпусток.

Наголошується на важливості вдосконалення нормативно-правової бази шляхом закріплення на законодавчому рівні отримання грошової компенсації за невикористані щорічні відпустки та виплати пенсійного забезпечення під час проходження військової служби в умовах правового режиму воєнного стану особам, які за вислугою років мають право на щорічну відпустку та пенсію. Зазначається, що проходження військової служби, її характер, підвищена небезпека для життя осіб, що її проходять, додаткові обов'язки, підвищені навантаження та додаткова відповідальність передбачають необхідність додаткових соціальних і правових гарантій для осіб, що її проходять.

Ключові слова: конституційні права та свободи військовослужбовців, обмеження прав та свобод військо- вослужбовців, військове законодавство, правовий режим воєнного стану.

\section{Summary}

Shamray B. M. Legal aspects of limitation of constitutional rights and freedoms of servicemen during the legal regime of martial law. - Article.

The article deals with the legal aspects of limiting the constitutional rights and freedoms of servicemen during the legal regime of martial law. The views of scholars on understanding the restrictions on the rights and freedoms of persons serving in the Armed Forces of Ukraine and other military formations are covered. It is noted that restrictions on the rights and freedoms of military personnel are objectively necessary, taking into account the specifics of military service, as well as related to the proper performance of duty, maintaining the proper level of combat and mobilization readiness of the troops (forces).

The normative legal acts that determine the basic principles of the state policy in the field of social protection of servicemen and regulate the passage of military service, which provide for certain restrictions on the constitutional rights and freedoms of servicemen in the conditions of the legal regime of martial law, are analyzed. It has been found out that a feature of the constitutional and legal status of military personnel is that in the performance of their military service duties, they enjoy the constitutional rights and freedoms with certain limitations provided by law and are determined by the peculiarities of military service. It is established that the limitation of the rights and freedoms of servicemen under the conditions of the martial law regime is conditioned by the fact that military personnel are subject to military legislation which restricts their individual constitutional rights, including the constitutional right to pension and annual leave, in addition to the general legislation.

Emphasizes the importance of improving the legal framework by fixing at the legislative level the receipt of monetary compensation for unused annual leave and the payment of retirement benefits during military service under the conditions of the martial law regime to persons who are entitled to annual leave for years of service. It is noted that the military service, its character, the increased danger to the lives of the persons passing it, the additional duties, the increased workload and the additional responsibility imply the need for additional social and legal guarantees for the persons passing it.

Key words: constitutional rights and freedoms of servicemen, restrictions on rights and freedoms of servicemen, military legislation, legal regime of martial law. 